Stefan Bringezu, Meghan O’Brien, Helmut Schütz

\title{
Beyond Biofuels: Assessing global land use for domestic consumption of biomass
}

A conceptual and empirical contribution to sustainable management of global resources

Originally published as:

Stefan Bringezu, Meghan O'Brien, Helmut Schütz (2012):

Beyond Biofuels: Assessing global land use for domestic consumption of biomass A conceptual and empirical contribution to sustainable management of global resources In: Land Use Policy, 29, 1, 224-232 


\title{
Beyond Biofuels: Assessing global land use for domestic consumption of biomass
}

A conceptual and empirical contribution to sustainable management of global resources

\author{
Stefan Bringezu ${ }^{\mathrm{a}, \mathrm{b}}$, Meghan $\mathrm{O}^{\prime}$ Brien $^{\mathrm{a}, \mathrm{c}}$ and Helmut Schütz ${ }^{\mathrm{a}, \mathrm{d}}$ \\ ${ }^{a}$ Wuppertal Institute for Climate, Environment and Energy \\ Döppersberg 19 \\ 42103 Wuppertal \\ Germany \\ www.wupperinst.org \\ ${ }^{\mathrm{b}}$ Corresponding Author \\ stefan.bringezu@wupperinst.org \\ tel. $+49(0) 202$ 2492-131 \\ fax. $+49(0) 2022492-138$ \\ ${ }^{\mathrm{c}}$ meghan.obrien@wupperinst.org \\ dhelmut.schuetz@wupperinst.org
}

\begin{abstract}
Consumption of natural resources should not exceed sustainable levels. The increasing use of biofuels and to some extent biomaterials, on top of rising food and feed demands, is causing countries to use a growing amount of global land, which may lead to land use conflicts and the expansion of cropland and intensive cultivation at the expense of natural ecosystems. Selective product certification cannot control the land use change triggered by growing overall biomass consumption. We propose a comprehensive approach to account for the global land use of countries for their domestic consumption, and assess this level with regard to globally acceptable levels of resource use, based on the concept of safe operating space. It is shown that the European Union currently uses one-third more cropland than globally available on a per capita basis and that with constant consumption levels it would exceed its fair share of acceptable resource use in 2030. As the use of global forests to meet renewable energy targets is becoming a concern, an approach to account for sustainable levels of timber flows is also proposed, based on the use of net annual increment, exemplified with preliminary data for Switzerland. Altogether, our approach would integrate the concept of sustainable consumption into national resource management plans; offering a conceptual basis and concrete reference values for informed policy making and urging countries to monitor and adjust their levels of resource consumption in a comprehensive way, respectful of the limits of sustainable supply.
\end{abstract}

Keywords: bioenergy, biomaterials, environmental space, consumption, agriculture, forestry 


\section{Introduction}

Sustaining land use for resource supply is often associated with the question of how to improve the cultivation of a certain hectare. At a higher scale, and in the context of global land cover and land use patterns, the question of how to control the demand for the number of cultivated hectares arises, in order to prevent the expansion of cropland and allow for globally sustainable supply. In this article we focus on the second question, although the answers are certainly interlinked, as higher yields per hectare allow more to be produced on less land, whereas, with various limits to further yield increases, growing demand will drive cultivation into other areas, potentially leading to conflict.

In recent years, many countries have established targets and quotas for the use of biofuels. While biofuels may appear to be a 'green solution' (substituting fossil fuels) in the country of consumption, their import may be associated with unintended side-effects. In the case of first-generation biofuels, which are now widely used, this could include the intensification and/or expansion of agricultural land with related losses of biodiversity, increased greenhouse gas emissions, increased water usage, water pollution and soil degradation, among others (for review of the environmental impacts see Bringezu et al. (2009a) or Howarth and Bringezu (2009)). Due to the increased competition for cropland, food prices have also been affected (FAO, 2008).

A key factor determining interregional problem shifting is the overall demand of land required for the production of biofuel feedstocks, and the competition for land by all other bio-based products, in particular food, but also biomaterials (incl. traditional uses of straw and wood). As a consequence, there has been a growing number of analysis and debate on how to quantify and assess the direct and indirect land use change induced by biofuels (e.g. Searchinger et al., 2008; Ravindranath et al., 2009; Al-Riffai et al., 2010; Hiederer et al., 2010). Indirect land use change induced by the production of energy crops may be associated with worse impacts than direct land use change and over-compensate GHG emission savings, as shown by Lapola et al. (2010) for Brazil. In all cases, estimates of induced direct and indirect land use change are subject to the fastidious nature of model parameters. Key parameters include the future development of yield increases -- which are rather uncertain -- as well as substitution effects between crops, products and regions and the non-linearity of marginal land requirements for extended croplands (Edwards et al., 2010). With the provision of ever more GHG estimates for specific types of biofuels, there is a real risk of getting lost in the details and losing sight of the big picture. In the meantime, competition for cropland is growing as indicated by the increased phenomena of 'land grabbing' (Cotula et al., 2009; FOE, 2010).

\footnotetext{
${ }^{1}$ In the last three years, 20 Mha are thought to have been acquired by foreign interests in Africa (Hallam, 2009)
} 
The current policy approach of setting mandatory biofuel quotas combined with certification of 'sustainable biofuel production' is insufficient for securing the overall sustainability of biomass use. The setting of sustainability standards for the production and import of biofuels (through land and product certification schemes) are promising developments for sustainable agriculture on-site, but powerless against increasing demand. For instance, even if certification requires that biofuels are produced on land that has not been recently converted from nature, indirect land use change cannot be avoided. This is just another form of problem shifting: it means that the food or feed cultivation the biofuel production replaced must be displaced elsewhere.

Assuming realistic yield increases, global cropland will have to expand only to feed the growing world population, especially to meet the need for increased protein content in developing countries (Bringezu et al., 2009a). Any additional demand for non-food crops must be expected to add to the overall demand for land, and thus contribute to the enhanced conversion of grasslands, savannahs and forests. The biggest cause of deforestation - and consequently loss of terrestrial biodiversity -- has been agricultural expansion (Lepers et al. 2005, MEA, 2005, Haines-Young, 2009). Business as usual scenarios foresee a further expansion of global agricultural land, both crop and pasture land, in the coming decades (OECD, 2008a; van Vuuren and Faber, 2009). One may assume that efforts such as REDD (Reduced Deforestation and Degradation of forests), which aim to shelter native forests, will also be insufficient as long as the global demand for biomass increases.

Agricultural land is not the only resource used by a growing biofuels industry. Another issue of growing concern is the increasing competition for woody biomass. For instance, in Europe, triggered by policies to support the shift to renewable energies, traditional industries like plywood manufacturing have been facing increased prices for raw materials that are also used for heating (Bringezu et al., 2008). Sweden aims to become 50\% renewable energy based by 2020 (Swedish Government, 2009). Although relatively rich in forests, Sweden like other Scandinavian countries, has become a net importer of bioenergy (Junginger et al., 2008), mainly in the form of pellets imported from British Columbia, South Africa and Australia. When advanced biofuel technologies are applied at a larger scale, the competition for wood and straw will increase further. From 1991 to 2005, Finland has increased timber imports from Russia - due to lower prices - while using only about two thirds of domestic annual forest growth. In Northwest Russia clear cut logging tended to change soft woods into birch forests (Stahls et al., 2010). This eventually leads to the question of what a sustainable level of forest use in various world regions, as well as globally, looks like. In addition, woody biomass use may not only affect forestry resources, but also agricultural land given the practice of cultivating plantations of, for instance, short-rotation coppice on cropland.

To set the stage for a sustainable biomass use, governments need to first widen their perspective from biofuels alone to biofuels as part of the greater agricultural and forestry system. 
They need to keep an eye on their countries' overall consumption of global food and nonfood biomass, as well as on the land needed to provide these resources. By looking at the entire system, they will then be able to identify those product groups which are linked to the domestic or foreign use of critical global resources, such as cropland. Adjusting the policy framework may then enable governments to motivate actors in industry and households to use more or less of those critical resources.

Thus governments need a reference point for assessing the sustainability implications of their policies on global resource consumption, and in particular land use. For that purpose, we will show how it is possible to

1. Monitor the global agricultural and forestry land already needed to supply domestic consumption of all agriculture and forestry products;

2. Compare this with how much land is available or biomass can be supplied under long-term conditions of sustainability.

\section{Methods, concepts and data used}

\subsection{The system considered}

Figure 1 illustrates the system of economies interconnected by trade and exchanging material flows with the environment. It is a perspective that clearly shows why it is necessary to look beyond the borders of the domestic environment: because supply comes from domestic extraction and imports. Countries extract or harvest resources from their own territory or use them via imports from other regions. Each country deposits waste and releases emissions to the atmosphere and water bodies. Theoretically, each country would have to make sure that the thresholds for sustainable resource use, emissions and waste disposal are not exceeded. In practice, however, only few countries have the capacities to monitor and control their domestic resource extraction, wastes and emissions. Moreover, the relevance of the environmental impacts and the acceptable level of pressures need to be assessed at different scales. For instance, acidification and eutrophication are usually assessed on a regional scale, whereas GHG emissions are evaluated against global references, while monitoring and control policies are enacted at the national level. In the case of a global sustainability threshold, the acceptable level of national emissions needs to be determined by considering a long-term global sustainability level (e.g. 2 tonnes GWP per capita in 2050) and using an appropriate rule for the attribution to each country (e.g. by the (Post-)Kyoto mechanisms). With regard to resource extraction and harvest, countries often issue mining licenses and may monitor the land used for agriculture and forestry. Worldwide, however, there seem to be very few cases of an overall resource planning, and especially of approaches that combine the use of abiotic and biotic resources. Moreover, neither regular monitoring nor methods of control currently exist for the levels of resource extraction associated with imports and exports. Thus the consumption of goods in a country - or a region like the EU - may lead to resource extraction in other 
countries, which altogether may exceed global or regional sustainability levels. This article is one of the first attempts to start the debate and trigger research on sustainable global land use by nations and regions. For that purpose, it may be assumed that the sum of the CARE (Capacity of Acceptable Resource Extraction) values of all countries add to a value of Globally Acceptable Resource Extraction (GARE), which - depending on the target indicator - may be measured either in terms of material resource extraction or land use.

Figure 1 Depicting how resource flows connect domestic consumption with world limits

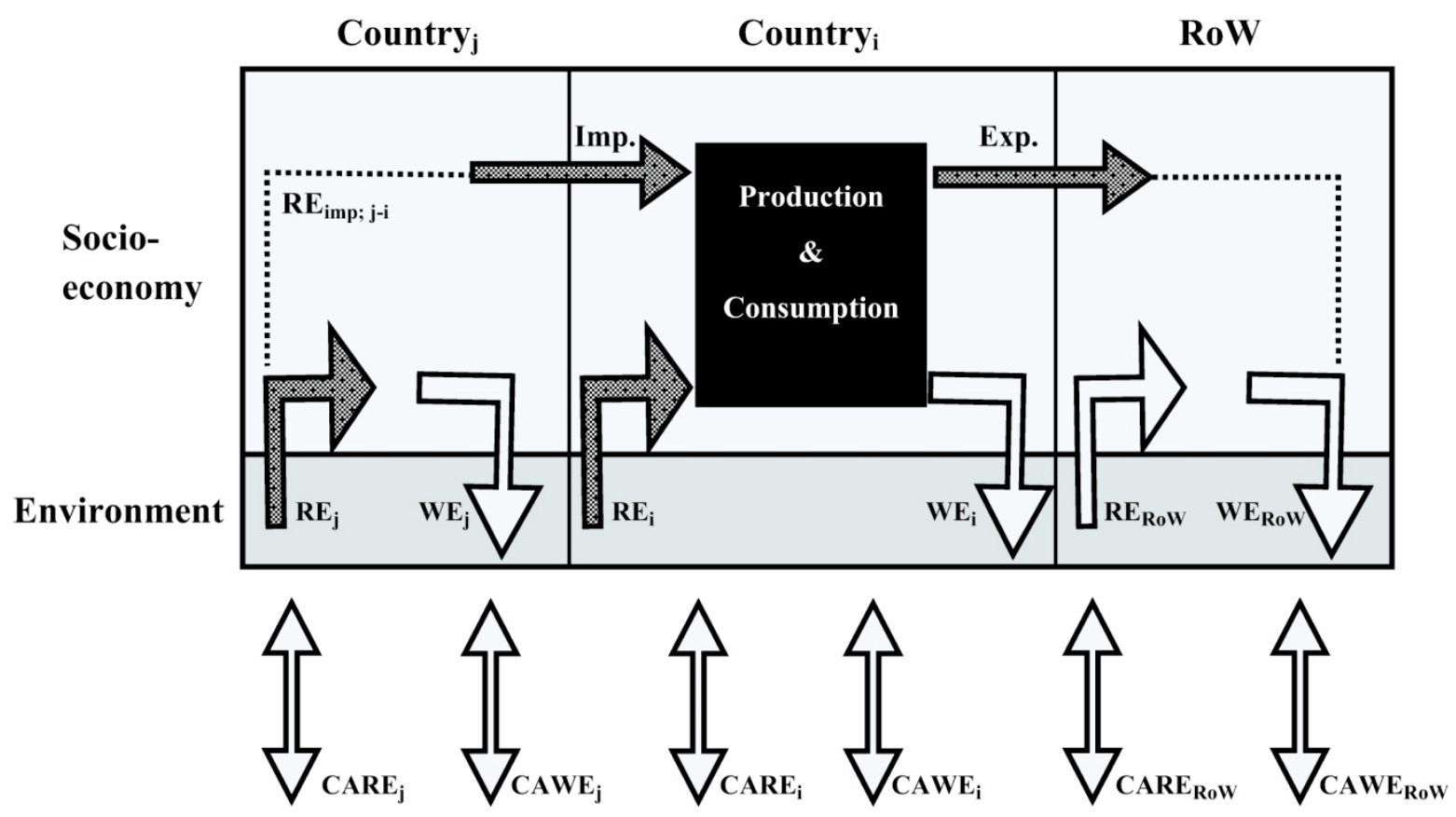

Notes:

$\mathrm{RE} \quad=$ Resource Extraction; it can be land use, mineral extraction, biomass harvest

$\mathrm{RE}_{\mathrm{i}} \quad=$ domestic Resource Extraction in country $\mathrm{i}$

$\mathrm{RE}_{\mathrm{imp} ; \mathrm{j}-\mathrm{I}}=$ Resource Extraction in country/region $\mathrm{j}$ for import to country $\mathrm{i}$ (cradle-to-products)

CARE = Capacity of Acceptable Resource Extraction in country/region i-n

CAWE = Capacity of Acceptable Waste disposal and Emission release in country/region i-n or

RoW= Rest of the World

WE $\quad=$ Waste and Emissions

\subsection{Calculating global land use for domestic consumption of biomass}

A method to account for the global use of cropland for domestic consumption has already been developed following the principles of economy-wide material flow accounting ${ }^{2}$. Global land use of agriculture $\left(\mathrm{GLU}_{\mathrm{A}}\right)$ is calculated using land for domestic production plus imports minus exports of all agricultural goods (referring to the dotted flows $R_{\text {imp;j-i }}$ in figure 1). So far, this method has been applied to Germany (see Bringezu et al. (2009b) for details), Switzerland (Zah et al., 2010), and for this article, to the European Union (the EU-27).

\footnotetext{
${ }^{2}$ Economy-wide material flow accounting is the monitoring of physical material flows across an economy. For more information see Eurostat (2001) and OECD (2008b).
} 
It is similar to the earlier approach of Erb (2004) for Austria, although developed independently, and it goes further than Kissinger and Rees (2010) who focussed only on the land for imports of the USA without quantifying that for exports.

The FAO classification of agricultural land types is used (see for instance Marklund and Batello, 2008). Thus, cropland includes land under temporary crops, meadows for mowing or pasture, gardens, and land temporarily fallow (less than five years) as well as permanent crops. For valid aggregation of national and transnational land use, categories of land use types -- such as 'agricultural land' - need to be accounted for in a comparable and consistent manner. In general, compared to other world regions all the domestic agricultural land within the EU-27 can be considered intensively managed. As regards imports and exports we distinguish 773 commodities by the 6-digits HS classification of the Eurostat Comext external trade statistics into primary crops (after the FAO classification), plant based products, and animal based products from agriculture. For imports of primary crops we apply the yield factors of FAOSTAT online which are specific by country of origin of imports and by year, while for exports of primary crops we use weighted yield factors from domestic production and imports. This seems justified as traded flows are usually minor in relation to domestic production, and transit flows are the exception. For plant based products we apply largely productivity figures relating to the domestic production in Germany derived from supply balances and production statistics of the German Ministry for Agriculture, as well as conversion coefficients (e.g. amount of flour per unit of wheat) derived from various other sources, and data derived from product specific LCA studies (e.g. Diers et al. 1999) and generic sources such as USDA-ERS $(1992,2005)$. For animal products we apply mainly productivity figures derived from feedstuff statistics - differentiated by domestic and foreign origin - and production statistics of the German Ministry for Agriculture for calculating the land use associated with imports and exports. We thus implicitly estimate for processed goods by and large a global agricultural land use for intensively managed systems. This may be quite realistic considering that crops (and derived products) for export are most likely from intensively used land, rather than from areas with marginal yields, but it may also underestimate the amount of international land required. The case of grassland is more difficult because grasslands in the EU are intensively used for grazing, whereas in other parts of the world use is extensive. Unpublished data from PBL/NL for intensively managed grasslands globally ${ }^{3}$ enabled us to calculate the global intensively managed agricultural area. We thus consider two categories of agricultural land use for this paper: cropland and intensively managed agricultural area (the

\footnotetext{
${ }^{3}$ By email communication with Stehfest, E., PBL/NL, on 30 August 2010 with reference to Klein Goldewijk et al. (2007). Based on grassland productivity modeled by the IMAGE crop model, the authors classified grasslands into intensive and extensive pastures. Data for total grassland are in line with FAOSTAT data for permanent pastures and meadows. Reference to the productivity level definition of extensive and intensive grassland is in Bouwman et al. (2006).
} 
latter consists of cropland plus intensively used grasslands, where cropland is arable land plus permanent crops).

As regards forestry products, land demand $\left(\mathrm{GLU}_{\mathrm{F}}\right)$ is determined in terms of forest area required to let the specific amount of timber for domestically consumed quantities of forestry products grow. This is derived from domestic production plus imports minus exports, i.e. apparent consumption. Based on available data (e.g. BAFU 2008 for Switzerland), area for import is calculated according to regions of origin (e.g. in the case of Switzerland 93\% stemming from EU-27) and their specific net annual increment (NAI; IIASA 2005). Area for exports is calculated based on weighted NAI according to domestic production and import share.

\subsection{Assessing global land use for sustainable consumption of biomass}

In order to provide a long-term sustainability reference for the assessment of global land use by countries, two components are considered: (a) information on an acceptable level of resource use at the global level, and (b) an adequate attribution to the consuming countries. In this section we focus on (a). As regards (b), we follow the concept of environmental space developed by Opschoor and Weterings (1994), applied to Europe by FOE (1995), and reviewed by Hille (1997) by attributing the access to and the use of global resources equally on a per capita basis, as this seems a reasonable basis for legitimate global governance of environmental limits (Bührs, 2009).

To determine an acceptable level of resource use at the global level we follow a somewhat different approach than the ecological footprint (EF) developed by Wackernagel and Rees (1996). The EF represents society's burden on the planet in theoretical global hectares combining actual and a larger virtual land use, which is dominated by the assumed terrestrial or maritime area required to absorb carbon dioxide emissions. The EF clearly shows that most countries are beyond their territorial carbon absorption capacities, which underpins the need for improved climate change mitigation (WWF et al., 2008). However, we think that the pressures to global warming and land use change are global issues which need separate monitoring and analysis for informed decision making. Thus we focus on determining a threshold for the rate of extraction of renewable resources based on actual land use, and recognize the importance of also determining thresholds for emissions and other globally relevant systemic pressures.

To this end, Rockström et al. (2009) made a courageous first step; they described a safe operating space for humanity by defining acceptable levels of 10 key environmental pressures. For eight key parameters they suggested a threshold, three of which have already been exceeded (climate change, biodiversity loss, and atmospheric nitrogen fixation). Those values were derived from recommendations of comprehensive dedicated research, like that of the IPCC, and expert judgment (Rockström et al., 2009). 
We agree to this deductive approach, as we think that globally acceptable levels of resource use can hardly be calculated and derived directly from any modelling. Although the complexity of interlinkages between human activities and the subsequent impacts and feedbacks with nature could be approximated by available models to a certain extent, there seem to be major uncertainties about tipping points (in nature and society, e.g. if food prices increase due to limited supply riots may be induced in poor countries which could trigger a turn-over of the political system); and moreover, there is a significant normative component about the decision of to which degree a change of environmental living conditions in different world regions is acceptable and at which levels the loss of natural habitats harbouring species diversity should be halted. For the latter, existing policy conventions and objectives, formulated e.g. by the $\mathrm{CBD}^{4}$ and the European Commission (EC, 2006), serve as a reference.

Depending on the aspiration of sustainable development, a range of sustainability targets may be defined. For instance, a more sustainable level of a country's (or region's) consumption with regard to cropland based products could be defined in a way that the country would require less cropland than what is expected to be used globally on a per capita basis under foresight conditions (moderate sustainability "level 1"). There would still be an expansion of global cropland - and loss of biodiversity - but the country would not excessively contribute to that development (at least less than others). If the country were to adopt a stronger control of its consumption this could theoretically compensate for the growing demand in other regions and halt the expansion of global cropland in a certain target year (strong sustainability "level 2").

Formally this can be expressed:

Actual Level (AL) of Total Resource Consumption (TRC): $\mathrm{AL}_{\mathrm{i}}=\mathrm{TRC}_{\mathrm{i}} / \mathrm{Pop}_{\mathrm{i}} / \mathrm{TRC}_{\mathrm{g}} / \mathrm{Pop}_{\mathrm{g}}$

$$
\text { If } \begin{aligned}
\mathrm{AL}_{\mathrm{i}} & =1 \mathrm{TRC}_{\mathrm{i}} \text { is average } \\
\mathrm{AL}_{\mathrm{i}} & >1 \mathrm{TRC}_{\mathrm{i}} \text { is above average } \\
\mathrm{AL}_{\mathrm{i}} & <1 \mathrm{TRC}_{\mathrm{i}} \text { is below average }
\end{aligned}
$$

In this case, country $y_{i}$ would achieve 'moderate sustainability' if its resource consumption were below the expected average resource consumption of the global population ( $\mathrm{Pop}_{\mathrm{g}}$ ). However, this does not consider the 'safe operating space' for resource consumption. For 'strong sustainability' a country must achieve a consumption level below the level of global-

\footnotetext{
${ }^{4}$ In 2002, Parties to the Convention on Biological Diversity (CBD) committed themselves to achieve a significant reduction of the current rate of biodiversity loss at the global, regional and national levels by 2010 . The global biodiversity outlook (2006) indicated amongst others that the loss of native forests still continued until 2006 at significant rates due to land use change.

${ }^{5}$ In this case moderate sustainability occurs if GRC $>$ GARE. If GRC $<$ GARE, AL below 1 would be sustainable.
} 
ly acceptable resource extraction (GARE) distributed equally among the global population. In other words:

Share of acceptable capacity (SHARE): $\quad$ SHARE $_{\mathrm{i}}=\mathrm{TRC}_{\mathrm{i}} / \mathrm{Pop}_{\mathrm{i}} / \mathrm{GARE}_{\mathrm{Pop}}$

If $\mathrm{SHARE}_{\mathrm{i}}=1 \mathrm{TRC}_{\mathrm{i}}$ is equal to an acceptable use of resource extraction

SHARE $_{\mathrm{i}}>1 \mathrm{TRC}_{\mathrm{i}}$ is above an acceptable use of resource extraction

SHARE $_{\mathrm{i}}<1 \mathrm{TRC}_{\mathrm{i}}$ is below an acceptable use of resource extraction

With data on "strong sustainability" we apply this broad and simple concept to the consumption of land use in agriculture as well as forestry, and to the net annual increment in forestry, in order to explore its possibilities, limitations and needs for further development.

\section{Results}

\subsection{Global land use of the European Union for consumption of agricultural goods}

In 2007 the EU-27 required 0.31 ha per capita of cropland worldwide for its overall consumption of agricultural goods (Figure 2a). This is one-third more than the globally available cropland per capita of the world population. Because population is increasing, the overall trend is for less cropland to be available per person. Since 2000, this trend can already be recognized, with a $7 \%$ decrease in world cropland per person until 2007 . While citizens of the EU also used less cropland worldwide, the rates of decline are different (only $3 \%$ in the EU).

Figure 2a Global cropland use for domestic consumption of agricultural goods in the EU27 and world cropland

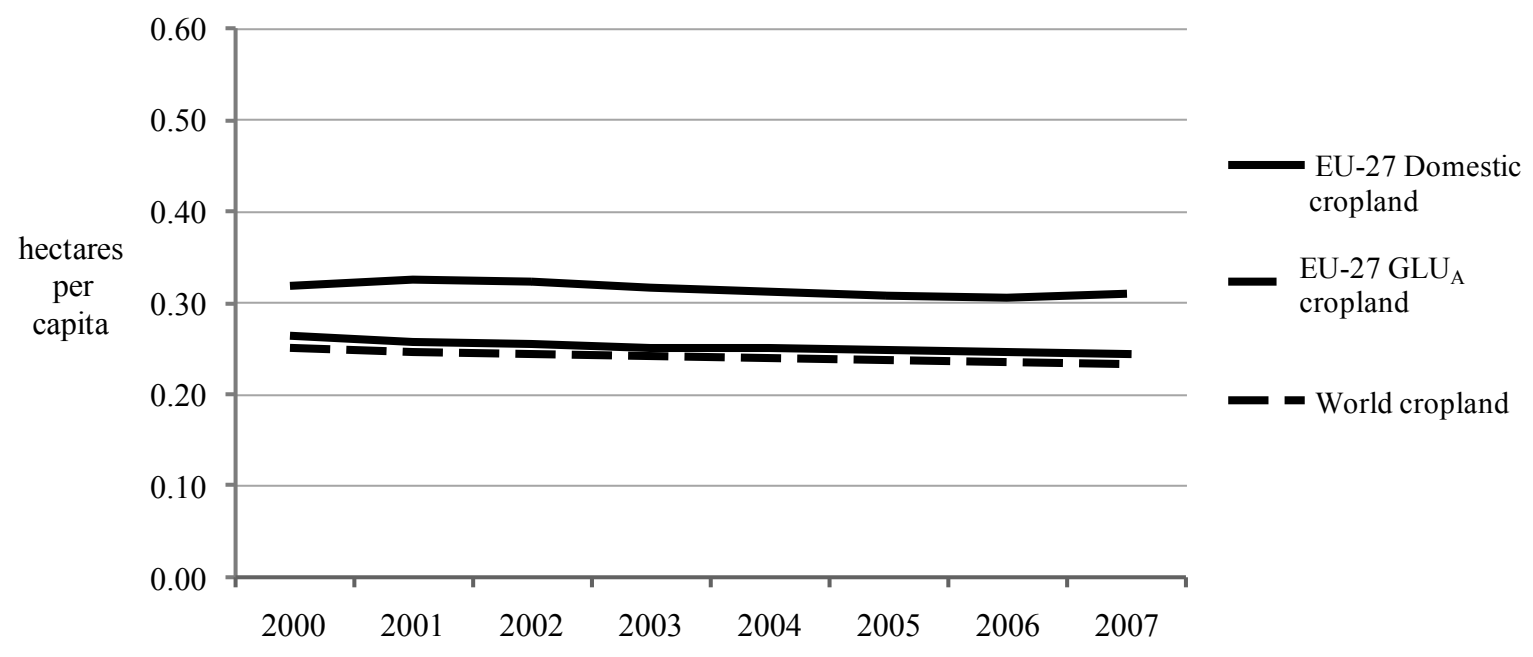

Looking at global intensive agricultural land, the EU-27 "consumed" 0.45 ha per capita in 2007 (Figure 2b). This is almost one-fifth more than the domestic agricultural area within the EU. Globally, 0.43 ha per capita of intensive agricultural land were available for the world population. Our result for the EU-27 GLU is corroborated by the findings of von 
Witzke und Noleppa (2010) following an independent approach. Trends since 2007 show a slightly more pronounced decline for the world (minus 5\% intensive agricultural land per person) than for the EU-27 (minus 4\%). The differences are, however, not really striking and the conclusion is that in terms of resource use of intensive agricultural land the EU-27 is more or less staying within the global average.

Figure 2b Global use of intensive agricultural land for domestic consumption of agricultural goods in the EU-27 and world intensive agriculture land

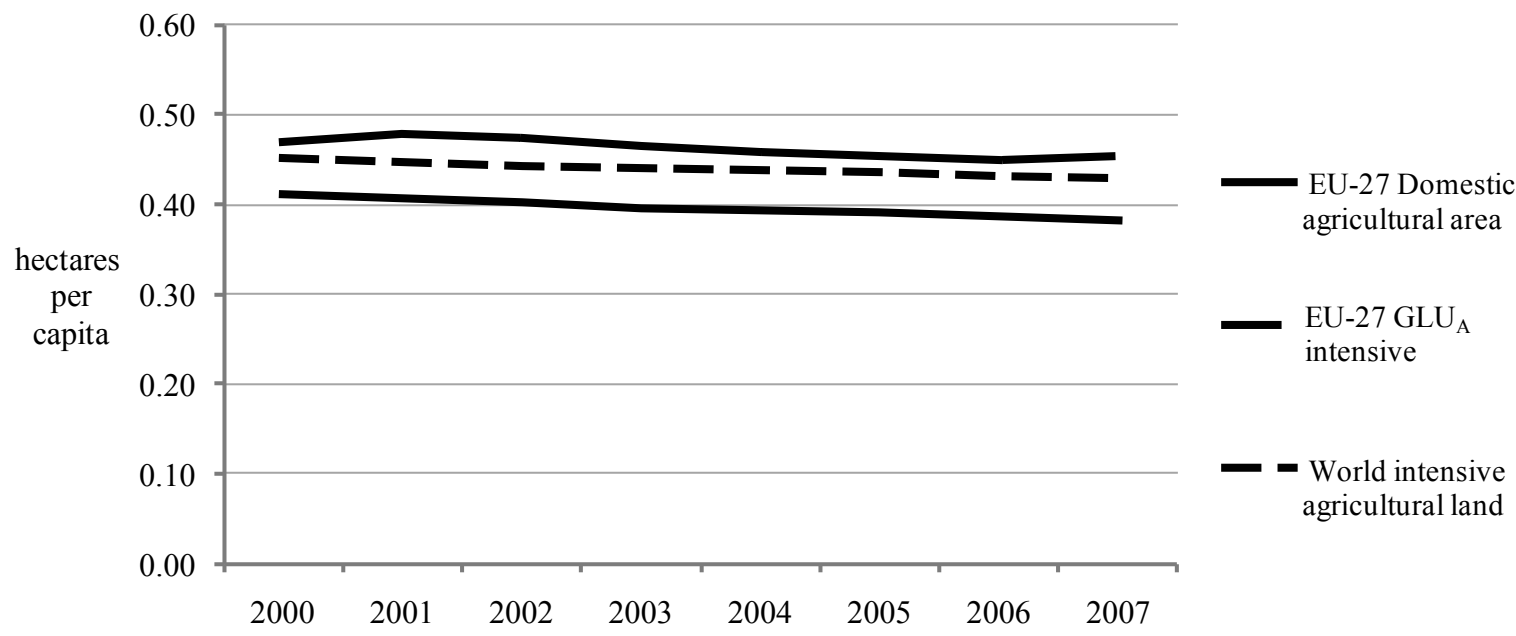

\subsection{Assessing global agricultural land use with respect to acceptable levels}

Determining how much global land is potentially available for long-term, sustainable cultivation needs to integrate available knowledge on the impacts of land use change, on the relation and functions of the various types of land use and land cover and decide on the acceptable risk for when that threshold may be trespassed. Rockström and colleagues suggested that a further expansion of 400 Mha of cropland would be within the safe operating space. While the authors explicitly aimed to control the loss of biodiversity caused by land use change, they did not seem to consider the expansion of settlement and infrastructure areas, which often occur on fertile land. Stretching 306 Mha in 2005, the built environment without policy intervention is expected to grow by up to nearly 250 Mha ( $81 \%$ ) by 2050 (Electris et al., 2009). According to Seto et al. (2010), urban area alone might expand between 40 and 143 Mha from 2007 to 2050 . Thus, there seems to be very limited room for expanding crop land. Although there are meanwhile vast stretches of land which has been abandoned, often because it has been degraded, it usually requires higher investments and knowledge capacities to restore its productivity compared to conversion of virgin natural land (for discussion see Bringezu 2009a). To stop the loss of biodiversity through cropland expansion, van 
Vuuren and Faber (2009) suggest that total agricultural land (including permanent pastures) should at least stabilize from 2020.

Using this as a preliminary guideline and considering that also a change from permanent pastures to cropland is usually associated with losses of biodiversity (MEA, 2005; Sala et al., 2009) as well as carbon (Fargione et al., 2008) and nutrient release, mainly depending on subsequent fertilization (in a range represented e.g. by Simpson et al. (2009) and Tilman et al. (2006)), we think that a cautious global target would be to halt the expansion of global cropland into grasslands, savannahs and forests by $2020^{1}$.

Starting from today's global average of roughly 0.24 ha per capita of cropland, the trend may lead to only 0.21 ha per capita in 2030 (van Vuuren and Faber 2009, trend scenario). Only to satisfy the increasing and changing food demand of the growing world population an up to $20 \%$ increase of global cropland can be assumed (Bringezu et al., 2009a), which would lead to roughly 0.22 ha per capita in 2030 . Following a strategy which aims at halting biodiversity loss due to land use changes and calls for halting expansion both of total agricultural land and cropland from 2020 one would arrive at ca 1.66 billion ha, respectively 0.20 ha cropland per capita in 2030. In any case, the current EU consumption of about 0.31 ha per capita would clearly exceed the globally available cropland for each world citizen. Even a further yield increase of $1 \%$ p.a. on average would not suffice to keep the EU's consumption below the global mean use of cropland. A further significant increase of non-food biomass demand, for instance for biofuels or biomaterials, has not been considered in those figures. Van Vuuren and Faber (2009) indicated that in particular diet change to low meat consumption and reduced post-harvest losses could bring about the changes required for meeting a cropland stabilization goal from 2020.

Similar conclusions may be derived from looking at intensive agricultural area, which may develop towards 0.37 ha per capita in 2030 worldwide $^{6}$. The current EU consumption of 0.45 ha per capita would also exceed the area used on average for each world citizen. A further yield increase of 1\% p.a. on average would bring the EU's consumption below the global mean use of intensive agricultural land. However, expectations on further yield increases have to face impacts of climate change (Lobell and Field, 2007) and limitations in water supply or side effects of nutrient pollution (Bringezu et al., 2009a).

For Germany, Bringezu et al. (2009b) compared the land already used for agricultural production to the land that would be needed to meet the overambitious policy targets for biofuels. Taking the globally used per capita cropland as a preliminary reference they concluded that Germany would have to reduce its global use of intensively used agricultural land which in 2004 exceeded domestic agricultural area by $21 \%$ - by one-quarter to one-third by 2030 in order to not surpass their global "fair share". They concluded that a net increase in

\footnotetext{
${ }^{6}$ Using the projections for cropland as described, plus projections for intensive global grassland from PBL/NL (see footnote 3 ).
} 
global use of intensively cultivated land and in greenhouse gas emissions would result from the increased use of biofuels, in particular from 1st generation biodiesel.

Applying the formal sustainability criteria to global agricultural land use of the EU27 , it becomes obvious that - at current resource use levels and assuming further yield increases of $1 \%$ p.a. on average - neither actual levels of cropland use (AL) nor shares of acceptable cropland use (SHARE) can be reached by 2030 (table 1). Indeed, even under conditions of (debatable) increasing yields 'moderate sustainability' criteria for cropland would be exceeded by ca. $15 \%$ and 'strong sustainability criteria' by around $19 \%$. Data on global intensive agricultural land use in 2030 depend on rather uncertain assumptions, and should be treated with caution. They may indicate that a further intensification of permanent pastures used for European consumption abroad could reduce some pressure on global land use. Future research should assess the validity of the assumptions made here and analyse different scenarios of consumption (for countries and regions) against moderate and strong sustainability references.

Table 1 The EUs global resource use of cropland and intensive agricultural land and global resource use levels

\begin{tabular}{|c|c|c|c|c|}
\hline & \multicolumn{2}{|c|}{$\begin{array}{c}\text { GLU }_{\mathrm{A}} \text { cropland in ha per } \\
\text { person }\end{array}$} & \multicolumn{2}{|c|}{$\begin{array}{l}\text { GLU } \mathbf{U}_{\mathrm{A}} \text { intensive agricultural } \\
\text { land in ha per person }\end{array}$} \\
\hline & 2007 & 2030 - trend & 2007 & 2030 - trend \\
\hline (1) $\mathrm{TRC}_{\mathrm{EU} 27} / \mathrm{POP}_{\mathrm{EU} 27}$ & $0.31^{b}$ & $(0.24)^{*}$ & $0.45^{\mathrm{b}}$ & $(0.35)^{*}$ \\
\hline (2) $\mathrm{GRC} / \mathrm{POP}_{\mathrm{g}}$ & $0.23^{b}$ & $0.21^{\mathrm{a}}$ & $0.43^{b}$ & $0.39^{\mathrm{a}}$ \\
\hline (3) GARE / POP & $0.20^{\mathrm{a}}$ & $0.20^{\mathrm{a}}$ & $(0.37)^{\mathrm{a}}$ & $(0.37)^{\mathrm{a}}$ \\
\hline $\mathrm{AL}=(1) /(2)$ & 1.33 & $(1.15)^{*}$ & 1.06 & $(0.90)^{*}$ \\
\hline SHARE $=(1) /(3)$ & 1.55 & $(1.19)^{*}$ & 1.22 & $(0.94)^{*}$ \\
\hline
\end{tabular}

Notes:

2030 - trend: from van Vuuren and Faber (2009) - trend scenario

()$^{*}$ - data is indicative only; derived from 2007 reference by assuming $1 \%$ p.a. average yield increase with other factors (consumption levels, population, etc.) remaining constant (highly uncertain)

a - data taken from van Vuuren and Faber (2009) for cropland and from PBL for intensive grassland

()$^{\mathrm{a}}$ - preliminary data derived from van Vuuren and Faber (2009) for cropland and from PBL for intensive grassland

b - calculations from this study based on FAO (for cropland) and PBL (for intensive grassland)

\subsection{Global land use of Switzerland for the consumption of forestry products}

Table 2 presents the results for scenarios ${ }^{7}$ analyzed by Zah et al. (2010). In 2006 the Swiss consumption of forestry goods required about $3500 \mathrm{~m}^{2}$ less global forestry land per

\footnotetext{
${ }^{7}$ In general, the scenario "resource scarcity" describes a high vegetarian diet, subsidized food by Swiss policy, and a world economic recession; scenario "unlimited growth" sets on low oil price, normal food supply and no global treaty on energy \& climate policy; while scenario "challenges" combines the features of high oil price, high meat consumption, food crises, world economy boom, sustainable biofuels support by Swiss policy, and global emission reduction treaty. The reference scenario depicts continued trend development.
} 
capita than what was available on a per capita basis for the world population (refer to line "Swiss minus World" in table 2). That means that on average, Swiss citizens used only about one-third of the per capita forestry land available on a global scale. All futures scenarios also revealed significantly lower per capita forest land requirements than global availability. This is because Switzerland imports about $93 \%$ of its total forestry products from the EU-27 (BAFU, 2008), where productivities are similarly high to those in Switzerland and significantly higher than the global average. While the results using forestland seem to indicate a low use of global forest resources, the results look very different if material flows $\left(\right.$ in $^{3}$ ) are accounted for instead (see table 3 ).

Table 2 Swiss global forestry land requirements for domestic consumption compared with the world population's availability of forest land (based on Zah et al., 2010)

\begin{tabular}{|c|c|c|c|c|c|}
\hline $\mathrm{m}^{2}$ per person & Status Quo & Reference & $\begin{array}{c}\text { Scenario 1 } \\
\text { Resource scar- } \\
\text { city }\end{array}$ & $\begin{array}{l}\text { Scenario } 2 \\
\text { Challenges }\end{array}$ & $\begin{array}{c}\text { Scenario } 3 \\
\text { Unlimited } \\
\text { growth }\end{array}$ \\
\hline & 2006 & 2030 & 2030 & 2030 & 2030 \\
\hline Biomaterials & 1,146 & 1,412 & 1,266 & 2,617 & 2,032 \\
\hline Bioenergy & 562 & 423 & 568 & 501 & 456 \\
\hline Total & 1,709 & 1,834 & 1,834 & 3,118 & 2,489 \\
\hline Self-supply ratio $\mathrm{GLU}_{\mathrm{F}}$ & $83 \%$ & $78 \%$ & $78 \%$ & $44 \%$ & $57 \%$ \\
\hline GLU $_{F}$ World & 5,210 & 4,133 & 4,133 & 4,133 & 4,133 \\
\hline Swiss minus World & $-3,501$ & $-2,299$ & $-2,299$ & $-1,015$ & $-1,645$ \\
\hline$A L=$ Total $/ G^{\prime L} U_{F}$ World & 0.33 & 0.44 & 0.44 & 0.75 & 0.60 \\
\hline
\end{tabular}

Table 3 Swiss global forestry biomass requirements compared with the world population's availability of forest biomass growth (based on Zah et al., 2010).

\begin{tabular}{|l|ccccc|}
\hline m & Status Quo & Reference & $\begin{array}{c}\text { Scenario 1 } \\
\text { Resource } \\
\text { scarcity }\end{array}$ & $\begin{array}{c}\text { Scenario 2 } \\
\text { Challenges }\end{array}$ & $\begin{array}{c}\text { Scenario 3 } \\
\text { Unlimited } \\
\text { growth }\end{array}$ \\
\hline & $\mathbf{2 0 0 6}$ & $\mathbf{2 0 3 0}$ & $\mathbf{2 0 3 0}$ & $\mathbf{2 0 3 0}$ & $\mathbf{2 0 3 0}$ \\
\hline Biomaterials & 0.54 & 0.77 & 0.78 & 2.33 & 1.75 \\
\hline Bioenergy & 0.30 & 0.28 & 0.50 & 0.40 & 0.35 \\
\hline TOTAL & 0.84 & 1.05 & 1.28 & 2.73 & 2.10 \\
\hline Self-supply ratio MFA & $91 \%$ & $90 \%$ & $98 \%$ & $40 \%$ & $52 \%$ \\
\hline Sustainable NAI World & 0.80 & 0.63 & 0.63 & 0.63 & 0.63 \\
\hline Swiss minus World & 0.04 & 0.41 & 0.64 & 2.10 & 1.47 \\
\hline SHARE & $\mathbf{1 . 0 5}$ & $\mathbf{1 . 6 5}$ & $\mathbf{2 . 0 1}$ & $\mathbf{4 . 3 1}$ & $\mathbf{3 . 3 2}$ \\
\hline
\end{tabular}




\subsection{Assessing global forestry land use with respect to acceptable levels}

Assessing the sustainable use of global forests by a country or a region is not straightforward. So far, similar to agriculture, unsustainable practices and trends have been reported and evaluated (e.g. FAO, 2006; ITTO, 2006) and sustainability measures have been aimed at the production side, for example by banning illegally harvested timber (e.g. The Lacey Act (US Government, 2008)) or improving certification (e.g. FSC certification). Two basic aspects need to be considered: (a) the extent of forest area, and (b) the quality of the forests, in particular with regard to productivity on the one hand and biodiversity on the other hand. In comparison to native forests, plantations provide higher yields but clearly support significantly lower levels of biodiversity (Koh and Wilcove, 2007; Stephens and Wagner, 2007). In order to prevent the further loss of biodiversity contained in forests, the forest area on all continents should not be diminished and native forests should not be converted into plantations. At the same time, countries differ with regard to natural endowment with forests, and depending on cultural geographic conditions, depend differently on forest resources (which, in contrast to food, renders it more difficult to interpret per capita consumption values globally).

With regard to sustainability conditions of forestry, one may assume that wood is removed only to a certain share of NAI growth (e.g. 80\% sustainable use of NAI). Based on IIASA (2005), UNECE/FAO (2005) and other statistical sources we estimated the global forestry area for wood supply at 0.521 ha per capita and the sustainable use of NAI at 0.8 $\mathrm{m}^{3} /$ capita* $\mathrm{yr}$ ( $80 \%$ of maximum value). This reference data should be considered preliminary.

In each scenario studied, the Swiss global consumption was higher than the estimated global NAI available on a per capita basis for the world population (Table 3). Only for past analysis (2006 status quo) was the Swiss consumption of forestry biomass within the global average availability per person. This indicates a future risk of over-proportional requirements for global forest resources by Switzerland. The Swiss self-supply ratio (SSR) of forest biomass was at $91 \%$ in 2006 , which underpins the importance of the country's forestry sector. The SSR would not change much in the reference scenario. Due to the maximum sustainable use of domestic forest biomass in scenario 1, the SSR would even go up to almost $100 \%$. In contrast, an increasing overall demand in scenarios 2 and 3, in particular for timber-based products, would lead to significant reductions of the self-supply ratio to levels between twofifths and two-thirds the domestic consumption and an exceedance of the sustainable resource share of up to 4 times.

\section{Discussion}

When the overall use of resources exceeds levels which can be supplied sustainably, it becomes necessary to limit that resource consumption and decouple it from further growth of 
wealth and well-being. Orientation towards a cap of global cropland use and attribution of this cap towards countries, quite analogously to GHG emission caps, will not imply a limit to further economic growth and prosperity. On the contrary, safe-guarding the supply of resources will underpin the physical basis of the economy, and an orientation towards a fair distribution of resource use between countries will foster an atmosphere of mutual trust and burden sharing, and thus also enhance international security.

In that sense, worldwide cropland is a resource which is globally used through the consumption of biotic goods, food, materials and energy. As available evidence seems to indicate an overuse of global cropland in terms of a safe operating space, countries are challenged to contribute to lowering their demand for that resource appropriately. This can be done by increasing efficiency in the use of biotic products, for instance, reducing food waste, and controlling policies which trigger the demand for those resources, such as biofuel quotas. As a basis for decision making, data is required that shows the contribution of various products and the activities in industry and households which are linked to the largest amount of global land use. On that basis, existing policies may be adjusted, perhaps supported by a few additional flanking measures, to "choice-edit" consumption patterns and in particular foster a system's wide more efficient use of biotic (and other) resources. There exist various options for enhancing the efficiency in the use of biomass, e.g. cascading use, reduction of wastes, improving fuel efficiency of car fleets, changed diets (Bringezu et al. 2009a).

In any case, monitoring is needed to let countries know how they stand, and science could provide a reference for what a 'sustainable development' could look like. Policy instruments could then direct countries towards progress; targeting decreased consumption of critical global resources and perhaps increased consumption of others.

One may question the concept of land as a global resource because conventional rights clearly define ownership and political sovereignty is usually linked to territorial autonomy. However, ownership is usually bound to responsible use, and in a globalised world national sovereignty has to cope with international interdependencies and principles of equity and burden sharing. The shrinking and degradation of global ecosystems like forests, due to the growing consumption of biotic resources, is both a national and regional, as well as a global challenge. Clearly, production and consumption in every country make use of foreign resources, including land, through imports and provide domestic resources for other countries' use through exports. Thus, responsibility also becomes a matter for those who consume and indirectly use others' resources, in particular when the resource use may contribute to an overuse of global capacities. This is particularly an issue for regions such as the EU as a "net consumer" of global cropland. The need to monitor and control the domestic consumption of global agricultural goods grows with the increasing globalization of food, feed, biofuel and biomaterial markets.

The orientation towards equal per capita values of resource consumption may be questioned because countries possess different endowments of natural resources. Forest rich 
countries may traditionally rely on timber resources to a higher degree than countries lacking large forests. Interestingly, countries with a strong forest based industry and traditionally widespread use of timber products, like Germany (Bringezu et al., 2009c), Sweden (Junginger et al., 2008) and Switzerland (Zah et al., 2010), are expected to exceed their national supply capacities and increasingly source timber from forests in other world regions. The question arises: to what extent can this growing demand be supplied sustainably? Our data indicate that, for instance, Switzerland may not only become more dependent on imports but also consume an over-average amount of global net annual forest increment, depending on the future development path they take. Certainly, the data basis for determining the global NAI needs to be improved. That said, our preliminary results indicate that governments, like in Switzerland, might consider policies which provide incentives for the use of timber for energy and biomaterials in a more moderated manner.

Also for cropland and agricultural land in general, one may question the orientation towards a globally equal per capita use with regard to the different endowments of countries with fertile soils and humid conditions, as well as technological means and know-how, which allow high yields and thus the potential to minimize cropland requirements. Future work should elaborate whether global land use targets should be specified for continents or biogeographical regions or development status. Still, however, one would have to consider that markets for agricultural commodities are - increasingly - globally linked, that food and nonfood biomass compete for fertile soils, that technological capacities are expected to further converge, and that people worldwide should be entitled to an equitable share of resource supply. As shown for forest products, the amount of hectares may be misleading, and the question arises whether the share of "global agricultural harvest" would be a better indicator than per capita cropland compared to the global average. Haberl et al. (2007) proposed human appropriation of net primary production (HANPP) as an indicator for the human domination of the eco-sphere. Their definition of HANPP includes the difference of net primary production (NPP) between the original vegetation without human influence and the actual NPP. The interpretation of HANPP embodied in trade and consumption by countries (Erb et al. 2009) seems difficult as areas with negative values (e.g. in irrigation zones) are summed up with areas showing positive values (e.g. where cropland converted primary forests), and a sustainable level of HANPP might be hard to define. Instead, and analogously to the NAI in forests, one may explore calculation and assessment of the NAI in agriculture under local sustainability conditions, worldwide and in the different world regions. This, however, seems to be a long-lasting effort, and it may not hinder the expansion of global cropland effectively and quickly enough. Thus, for the coming decade(s), as land use policy is going to become also an issue of all product and consumption related policies, decision makers may be informed based on real global hectares of cropland (and equivalent land). At least for Europe, where growing conditions are favourable and technologies are above the global average, our data 
indicate that consumption is already beyond what may be deemed sustainable, although assumptions and data certainly need discussion and refinement.

Finally, it should be clarified that our approach presents a method to account for sustainable levels of consumption. It is relevant for land use and the reproductive potential of biomass at the country scale and needed to support decision making of national or regional governments, as well as industry and NGOs. Sustainable management of resources will nevertheless require action at various scales. At the field scale, principles of good agricultural and forestry practice need to secure soil fertility, minimize nutrient pollution and erosion and foster an efficient use of water. The better local resources are managed, the less the need to shift cultivation away from degraded land. Production related standards are therefore necessary to ensure the proper management of each hectare, and product certification may help to promote this via the demand for selected products. At the same time, these standards do not control the overall demand of products and therefore need to be complemented by the measurements and references described in this article for the economy-wide management of the number of hectares and the share of biotic regeneration capacity. Not least, our approach contributes to the further development of land change science and to complement the prevailing perspective to "micromanage the physical world" (Turner et al. 2007) with approaches of macromanagement which effectively addresses the driving forces of resource consumption.

\section{Conclusions}

The measurement of global land use for the consumption of agricultural goods allows the combined effect of food and non-food demand on global environmental pressures, such as the expansion of cropland, to be compared. For the EU-27 the available data indicate that the consumption level in 2007 -- when the use of biofuels was still rather low, at $2.6 \%$ of total final energy consumption of petrol and diesel for transport (EC, 2010) -- exceeded the assumed equitable world level. With constant proportions of biomass based product consumption, the expected level in 2030 following business-as-usual might also be beyond sustainable levels. One may conclude that the envisioned additional supply of biofuels, as long as they are cropland based, triggered through the renewable energy quota for transport fuels in the EU, will add to the pressure of cropland expansion mainly in (tropical) regions outside the EU. Selected certification for biofuels will not hinder indirect land use changes for the supply of - noncertified - food. The increasing use of forest products - for bioenergy and material purposes - may also face limits of global sustainable supply. Thus, renewable energy and biomaterials policies need to be further developed and integrated into sustainable biomass action programmes - and moreover into an economy-wide sustainable resource management scheme (Bringezu, 2011) - which considers the consumption of food and non-food biomass and its related land use and environmental effects both within and outside the EU. The concept, data and assumptions presented here should be further refined and tested for applicabil- 
ity. Global land use accounting should become part of EU's official reporting ${ }^{8}$. Future modelling of global land use changes will need to consider the growing demand for both food and non-food biomass. Purely sectoral analysis of certain biomass products will be inadequate to assess land use change related effects induced by countries and regions. Although data and classifications presented will need to be refined by future work, our approach may help to provide the basis for redirecting national and regional policies affecting biomass consumption, for instance by prioritizing and optimizing food supply while restricting non-food biomass consumption.

\section{References}

Al-Riffai, P., Dimaranan, B. and Laborde, D., 2010. Global Trade and Environmental Impact Study of the EU Biofuels Mandate. The International Food Policy Research Institute, ATLASS Consortium.

BAFU, 2008. Jahrbuch Wald und Holz. [Swiss statistical yearbook of forestry.] Federal Office of the Environment. Bern.

Bouwman, A.F., Van der Hoek, K.W., and Van Drecht, G., 2006. Modelling livestock-cropland use interactions in global agricultural production systems. In: MNP (2006) Integrated modelling of global environmental change. An overview of IMAGE 2.4. Netherlands Environmental Assessment Agency (MNP), The Netherlands.

Bringezu, S., Schütz, H., Arnold, K., Bienge, K., Borbonus, S., Fischedick, M., von Geibler, J., Kristof, K., Ramesohl, S., Ritthoff, M., Schlippe, H., Frondel, M., Janßen-Timmen, R., and Vance, C., 2008. Nutzungskonkurrenzen bei Biomasse: Auswirkungen der verstärkten Nutzung von Biomasse im Energiebereich auf die stoffliche Nutzung in der Biomasse verarbeitenden Industrie und deren Wettbewerbsfähigkeit durch staatlich induzierte Förderprogramme. [Competing Uses of Biomass - Consequences of the Reinforced Use of Biomass for Energy on the Material Use in the Biomass Processing Industry and its Competitiveness through State Induced Support Programmes.] German Federal Ministry of Economics and Technology.

Bringezu, S., Schütz, H., O’Brien, M., Kauppi, L., Howarth, R.W., and McNeely, J., 2009a. Towards sustainable production and use of resources: Assessing Biofuels. International Panel for Sustainable Resource Management, United Nations Environment Program.

Bringezu, S., Schütz, H., Arnold, K., Merten, F., Kabasci, S., Borelbach, P., Michels, C., Reinhardt, G.A., and Rettenmaier, N., 2009b. Global implications of biomass and biofuel use in Germany - Recent trends and future scenarios for domestic and foreign agricultural land use and resulting GHG emissions. Journal of Cleaner Production 17: $57-68$.

Bringezu, S., Schütz., H., Schepelmann, P., Lange, U., von Geibler, J., Bienge, K., Kristof, K., Arnold, K., Merten, F., Ramesohl, S., Fischedick, M., Borelbach, P., Kabasci, S., Michels, C., Reinhardt, G.A., Gärtner, S., Rettenmaier, N., Münch, J., 2009c. Nachhaltige Flächennutzung und nachwachsende Rohstoffe: Optionen einer nachhaltigen Flächennutzung und Ressourcenschutzstrategien unter besonderer Berücksichtigung der nachhaltigen Versorgung mit nachwachsenden Rohstoffen. [Sustainable land use and renewable resources: Options for a sustainable land use and resource strategy un-

\footnotetext{
${ }^{8}$ The EEA has shown interest and intends to provide such data.
} 
der consideration of the sustainable supply of renewable resources.] Umweltbundesamt, Texte 34/2009.

Bringezu, S., 2011. Key elements of economy-wide sustainable resource management. Annales de Mines 61, 78-87.

Bührs, T., 2009. Environmental Space as a Basis for Legitimating Global Governance of Environmental Limits. Global Environmental Politics 9(4), 111-135.

Cotula, L., Vermeulen, S., Leonard, R., and Keeley, J., 2009. Land grab or development opportunity? Agricultural investment and international land deals in Africa. FAO, IIED, IFAD, London/Rome.

Destatis, 2010. Erweitertes Input-Output Modell für Energie und Treibhausgase. Methoden und Ergebnisse. [Extended Input-Output Model for energy and GHG gases. Methods and results.] Federal Statistical Office Germany, Wiesbaden.

Diers, A., Langowski, H.-C., Pannkoke, K., Hop, R., 1999. Produkt-Ökobilanz vakuumverpackter Röstkaffee - LCA Study on Vacuum Packed Roasted Coffee. Bayreuth: Eco-Informa Press, 1999, 214 S. LCA Documents, 3, ISBN: 3-928379-55-0.

Edwards, R., Mulligan, D.. and Marelli, L., 2010. Indirect land use change from increased biofuels demand: comparison of models and results for marginal biofuels production from different feedstocks. JRC-IE. European Union, Luxembourg Publications Office.

Electris, C., Raskin, P., Rosen, R., and Stutz, J., 2009. The Century Ahead: Four Global Scenarios. Technical Documentation. Tellus Institute.

Erb, K.-H, 2004. Actual land demand of Austria 1926-2000: a variation on Ecological Footprint assessments. Land Use Policy 21(2004), 247-259.

Erb, K.-H., Krausmann, F., Lucht, W., Haberl, H. Embodied HANPP, 2009: Mapping the spatial disconnect between global biomass production and consumption. Ecological Economics 69 (2009) 328-334.

EC (European Commission), 2006. Halting the Loss of Biodiversity By 2010 - and Beyond. Sustaining ecosystem services for human well-being. COM(2006) 216 final.

EC, 2010. EU energy and transport in figures. Statistical Pocketbook 2010. http://ec.europa.eu/energy/publications/statistics/doc/2010_energy_transport_figures.p df.

EU (European Union), 2005. Thematic Strategy on the sustainable use of natural resources. Communication from the Commission to the Council, the European Parliament, the European Economic and Social Committee and the Committee of the Regions, $\operatorname{COM}(2005) 670$. Brussels, 21.12.2005.

EUROSTAT - Statistical Office of the European Communities (ed). 2001. Economy-wide material flow accounts and derived indicators. A methodological guide. European Communities, Luxembourg. http://epp.eurostat.cec.eu.int/cache/ITY_OFFPUB/KS34-00-536/EN/KS-34-00-536-EN.PDF.

FAO (Food and Agricultural Organization of the United Nations), 2006. Global Forest Resource Assessment 2005: Progress towards sustainable forest management. FAO Forestry Paper 147, Rome.

FAO, 2008. The state of food and agriculture 2008. Biofuels: prospects, risks and opportunities. Rome.

Fargione, J., Hill, J., Tilman, D., Polasky, S., and. Hawthorne, P., 2008. Land clearing and the biofuel carbon debt. Science 319, $1235-1238$.

FOE (Friends of the Earth), 1995. Towards Sustainable Europe: the study. Friends of the Earth Europe, Brussels.

FOE, 2010. Africa: up for grabs: the scale and impact of land grabbing for agrofuels. Friends of the Earth Europe, Brussels. 
Goldewijk, K., Bouwman A.F., and van Drecht, G., 2007. Mapping contemporary global cropland and grassland distributions on a 5 by 5 minute resolution. Journal of Land Use Science 2(3), 167-190.

Haberl, H., Erb, K.-H., Krausmann, F., Gaube, V., Bondeau, A., Plutzar, C., Gingrich, S., Lucht, W., Fischer-Kowalski, M., 2007. Quantifying and mapping the human appropriation of net primary production in earth's terrestrial ecosystems. PNAS 104, $12942-$ 12947

Hallam, D., 2009. Foreign Investment in Developing Country Agriculture - Issues, Policy Implications and International Response. Paper presented at the OECD Global Forum on International Investment VIII, 7-8 December 2009.

Haines-Young, R., 2009, Land use and biodiversity relationships. Land Use Policy 26S, S178-S186.

Hiederer, R., Ramos, F. Capitani, C., Gomez, O., Koeble, R., Blujdea, V., Mulligan, D., Edwards, R., and Marelli, L., 2010. Estimation of marginal GHG emissions from Soils following Global Land Use Change caused by the Production of Biofuels. A methodology involving spatial allocation of agricultural land demand, calculation of carbon stocks and estimation of $\mathrm{N} 2 \mathrm{O}$ emissions. Available at http://re.jrc.ec.europa.eu/bf-tp/.

Hille, J., 1997. The Concept of Environmental Space. Implications for Policies, Environmental Reporting and Assessments. European Environment Agency, Copenhagen.

Howarth, R.W. and Bringezu, S. (eds.), 2009. Biofuels: Environmental Consequences and Interactions with Changing Land Use. Report of the International SCOPE Biofuels Project.

IIASA (International Institute for Applied Systems Analysis), 2005. Land appropriation of the forest sector. Land Use Change and Agriculture Project. Available at http://www.mosus.net/documents-reports.html.

ITTO (International Tropical Timber Organization), 2006. Status of Tropical Forest Management 2005. ITTO Technical Series No 24.

Junginger, M., Bolkesjø, T., Bradley, D., Dolzan, P., Faaij, A., Heinimoe, J., Hektor, B., Leistad, Ø., Ling, E., Perry, M., Piacente, E., Rosillo-Calle, F., Ryckmans, Y., Schouwenberg, P.-P., Solberg, B., Trømborg, D., da Silva Walter, A., and de Wit., M., 2008. Developments in international bioenergy trade. Biomass and Bioenergy 32, 717-729.

Kissinger, M., Rees, W., 2010. Importing terrestrial biocapacity: The U.S. case and global implications. Land Use Policy 27, 589-599.

Koh, L. P. and Wilcove, D. S., 2007. Cashing in palm oil for conservation. Nature 448, 993994.

Lapola, D.M., Schaldach, R., Alcamo, J., Bondeau, A., Koch, J., Koelking, C., and Priess, J.A., 2010. Indirect land-use changes can overcome carbon savings from biofuels in Brazil. PNAS direct submission; http://www.pnas.org/content/early/2010/02/02/0907318107.

Lepers, E., Lambin, E.F., Janetos, A.C., DeFries, R., Achard, F., Ramankutty, N., Scholes, R.J., 2005. A synthesis of information on rapid land-cover change for the period 1891-2000. BioScience 55 (2), 115-124.

Lobell, D.B. and Field, C.B., 2007. Global scale climate crop yield relationships and the impacts of recent warming. Environmental Research Letters 2, 014002 (7pp).

Marklund, L.G., and Batello, C., 2008. FAO datasets on land use, land use change, agriculture and forestry and their applicability for national greenhouse gas reporting. A background paper for the IPCC Expert meeting on Guidance on Greenhouse Gas In- 
ventories of Land Uses such as Agriculture and Forestry. Helsinki, Finland 13-15 May 2008.

MEA (Millenium Ecosystem Assessment),_2005. Ecosystems and Human Well-Being: Synthesis. Island Press, Washington, DC.

OECD, 2008a. OECD Environmental Outlook to 2030. OECD, Paris.

OECD, 2008b. Measuring material flows and resource productivity. Synthesis report. Organisation for Economic Cooperation and Development, Paris.

Opschoor, J.B. and Weterings R., 1994. Environmental Utilisation Space: An Introduction. Tijdschrift Voor Milieukunde 9(4), 198-205.

Ravindranath, N.H., Sathaye, J., Woods, J., Fargione, J., Watson, H., Faaji, A., Makundi, W., and Canadell, P., 2009. GHG Implications of Land Use and Land Conversion to Biofuel Crops. In R.W. Howarth and S. Bringezu (eds.) Biofuels: Environmental Consequences and Interactions with Changing Land Use. Report of the Internatinal SCOPE Biofuels Project. http://cip.cornell.edu/biofuels/.

Rockström, J., Steffen, W., Noone, K., Persson, Å., Chapin III, F.S., Lambin, E.F., Lenton, T.M., Scheffer, M. Folke, C., Schellnhuber, H.J., Nykvist, B., de Wit, C.A., Hughes, T., van der Leeuw, S., Rodhe, H., Sörlin, S., Snyder, P.K., Costanza, R., Svedin, U., Falkenmark, M., Karlberg, L., Corell, R.W., Fabry, V.J., Hansen, J., Walker, B., Liverman, D., Richardson, K., Crutzen, P., and Foley, J.A., 2009. A safe operating space for humanity. Nature 461, 472-475.

Sala, O.E., Sax, D., and Leslie, L., 2009. Biodiversity Consequences of Increased Biofuel Production. In R.W. Howarth and S. Bringezu (eds.) Biofuels: Environmental Consequences and Interactions with Changing Land Use. Report of the Internatinal SCOPE Biofuels Project. http://cip.cornell.edu/biofuels/.

Searchinger, T., Heimlich, R., Houghton, R.A., Dong, F., Elobeid, A., Fabiosa, J., Toggoz, S., Hayes, D., and Yu, T.-H., 2008. Use of U.S. croplands for biofuels increases greenhouse gases through emissions from land use changes. Science 319(5867), 12381240.

Seto, K., Bringezu, S., de Groot D., Erb, K.-H., Graedel, T.E., Ramankutty, N., Reenberg, A., Schmitz, O. and Skole, D.L., 2009. Stocks, flows and prospects of land. In Linkages of Sustainability, edited by T.E. Graedel and E. van der Voet. Strungmann Forum Report, vol. 4., MIT Press, Cambridge, MA.

Simpson, T.W., Martinelli, L.A., Sharpley, A.N., and Howarth, R.W., 2009. Impact of ethanol production on nutrient cycles and water quality: the United Staes and Brazil as case studies. In R.W. Howarth and S. Bringezu (eds.) Biofuels: Environmental Consequences and Interactions with Changing Land Use. Report of the Internatinal SCOPE Biofuels Project. http://cip.cornell.edu/biofuels/.

Stahls, M.H., Mayer, A.L., Tikka, P.M., and Kauppi, P.E., 2010. Disparate geography of consumption, production, and environmental impacts. Forest Products in Finland 19912007. Journal of Industrial Ecology 14(4), 576-585.

Stephens, S.S. and Wagner, M.R., 2007. Forest Plantations and Biodiversity: A Fresh Perspective. Journal of Forestry 105(6), 307-313.

Swedish Government, 2009. An integrated climate and energy policy: Information sheet about the government bills 2008/09:162 and 163. Ministry of the Environment, Ministry of Enterprise, Energy and Communications.

Tilman, D., Hill, J., and Lehman, C., 2006. Carbon negative biofuels from low-input highdiversity grasslands. Science 314: 1598-1600. 
Turner, B.L., Lambien, E.F., Reenberg, A., 2007. The emergence of land change sci- ence for global environmental change and sustainability. PNAS 104 (52), online: http://www.pnas.org/content/104/52/20666.full.

UNECE/FAO, 2005. European Forest Sector Outlook Study (EFSOS): 1960-2000-2020, Geneva Timber and Forest Study Paper 20, United Nations, Geneva. ECE/TIM/SP/20. http://timber.unece.org/.

USDA-ERS, 1992. Weight, Measures and Conversion Factors for Agricultural Commodities and their Products. http://www.ers.usda.gov/publications/ah697/ah697.pdf.

USDA-ERS, 2005. Food Availability Spreadsheets., www.ers.usda.gov/data/ foodconsumption/FoodAvailSpreadsheets.htm.

S Government, 2008. Lacey Act Amendments: Legal Timber Protection Act. H.R. 1497. Report No. $110-882$.

van Vuuren, D.P. and Faber, A., 2009. Growing within Limits. Netherlands Environmental Assessment Agency.

von Witzke, H. and Noleppa, S., 2010. EU agricultural production and trade: can more efficiency prevent increasing 'land-grabbing' outside of Europe? Humboldt University Berlin, Agripol. OPERA.

Wackernagel, M. and Rees, W.E., 1996. Our Ecological Footprint: Reducing Human Impact on the Earth. New Society Publishers, Gabriola Island, BC.

WWF (World Wildlife Fund), ZSL (Zoological Society of London), und Global Footprint Network, 2008. Living Planet Report.

Zah, R., Binder, C., Bringezu, S., Reinhard, J, Schmid, A., and Schütz, H., 2010. Future perspectives of 2 nd generation biofuels. Centre for Technology Assessment, TA-SWISS 55/2010. Vdf Hochschulverlag AG an der ETH Zürich.

\footnotetext{
${ }^{1}$ Note: agricultural land, in particular cropland, which has been abandoned is no longer accounted under this category; it is to be distinghuished from set aside land which is only temporarily out of use by farmers
} 